\title{
Reconstructing the Late Palaeozoic - Mesozoic topographic evolution of the Chinese Tian Shan: available data and remaining uncertainties
}

\author{
M. Jolivet ${ }^{1}$, G. Heilbronn ${ }^{1}$, C. Robin ${ }^{1}$, L. Barrier ${ }^{2}$, S. Bourquin ${ }^{1}$, Zh. Guo ${ }^{3}$, Y. Jia ${ }^{4}$, L. Guerit ${ }^{2}$, W. Yang ${ }^{1,3}$, and B. Fu ${ }^{4}$ \\ ${ }^{1}$ Géosciences Rennes, CNRS - Univ. Rennes 1 - Observatoire des Sciences de L'Univers de Rennes (OSUR), Rennes, France \\ ${ }^{2}$ Institut de Physique du Globe de Paris, Sorbonne Paris Cité, Université Paris Diderot, UMR CNRS 7154, 1 rue Jussieu, \\ 75005 Paris, France \\ ${ }^{3}$ School of Earth and Space Sciences, Peking University, Beijing, China \\ ${ }^{4}$ Center for Earth Observation and Digital Earth, Chinese Academy of Sciences, Beijing, China
}

Correspondence to: M. Jolivet (marc.jolivet@univ-rennes1.fr)

Received: 4 February 2013 - Revised: 2 July 2013 - Accepted: 23 August 2013 - Published: 17 December 2013

\begin{abstract}
The topographic evolution of continents and especially the growth and dismembering of mountain ranges plays a major role in the tectonic evolution of orogenic systems, as well as in regional or global climate changes. A large number of studies have concentrated on the description, quantification and dating of relief building in active mountain ranges. However, deciphering the topographic evolution of a continental area submitted to recurrent tectonic deformation over several hundred millions of years remains a challenge. Here we present a synthesis of the tectonic, geochronological and sedimentological data available on the intracontinental Tian Shan Range to describe its general topographic evolution from Late Palaeozoic to Early Tertiary. We show that this evolution has occurred in two very distinct geodynamic settings, initiating during the Carboniferous in an ocean subduction - continent collision tectonic context before becoming, from Early Permian, purely intra-continental. We show that during most of the Mesozoic, the topography is mostly characterized by a progressive general decrease of the relief. Nonetheless localized, recurrent deformation induced the formation of small-scale reliefs during that period. These deformations were driven by far field effects of possibly several geodynamic processes in a way that still remains to be fully understood.
\end{abstract}

\section{Introduction}

It is now largely accepted that the tectonic evolution of mountain ranges, climatic variations and feedback between the two is intimately linked to the topographic evolution of orogenic belts (e.g. Molnar and England, 1990; Batt and Braun, 1999; Whipple and Mead, 2006). Indeed, the topographic growth of an orogenic relief can influence the regional and sometimes global climate (e.g. Raymo and Ruddiman, 1992; Ramstein et al., 1997; Bookhagen and Burbank, 2006; Molnar et al., 2010). In turn, topographic changes due to climatic variations, which can modify the erosion rate and pattern in a range, can affect a tectonic evolution by, for example, impeding or accelerating the propagation of the deformation (e.g. Willett, 1999; Wobus et al., 2003; Thiede et al., 2004; Whipple, 2009). For those reasons, a large number of studies recently concentrated on describing the topographic evolution of active mountain ranges over a period of time spanning from a few thousands of years (e.g. Vassallo et al., 2007a; Nissen et al., 2009) to a few tens of million years (e.g. Metivier and Gaudemer, 1997; Sobel and Strecker, 2003; Yin, 2006; Liu-Zhen et al., 2008). In contrast, deciphering the topographic evolution of a mountain range area over several hundred millions of years remains a challenge and only a few studies have addressed that issue (e.g. Hendrix et al., 1992; Hendrix, 2000; Juez-Larré et al., 2010). However, understanding the long-term evolution of the topography is of primary interest to understand the relief and sedimentary basin dynamics in orogenic areas, the structural 
and topographic inheritage in present day mountain ranges, or regional and global climate evolutions. The Tian Shan is one of the main intra-continental mountain ranges in Central Asia (Fig. 1). It forms a strong orographic barrier blocking the fresh and humid air masses coming from Siberia to the north and northwest, preventing them to reach the Tarim Basin and the Tibetan Plateau (e.g. Li et al., 2011; Zhao et al., 2013). The late Oligocene to Present growth of the Tian Shan Range resulted from crustal shortening related to the ongoing India-Asia collision (e.g. Tapponnier et al., 1986; Yin, 2010). However, the large-scale structure of the Tian Shan lithosphere was set by complex accretions of island arcs and amalgamation of continental blocks during the whole Palaeozoic (e.g. Windley et al., 1990; Charvet et al., 2011). This initial structure that was completely established by Late Permian, and especially the major tectonic boundaries separating the various terranes played a first order role in the subsequent evolution of the range.

The Palaeozoic and Cenozoic tectonic evolutions of the Tian Shan have been and are still widely studied and discussed. However, while the Mesozoic tectonic evolution of the range seems to have a major impact on its Tertiary development and topography (e.g. Dumitru et al., 2001; De Grave et al., 2007; Glorie et al., 2010; Jolivet et al., 2010), many uncertainties remain on the topographic evolution of the range during that period separating the two main orogenic events.

Here we present a short synthesis of the available data in order to draw a general picture of the topographic evolution of the Tian Shan from Late Palaeozoic to Early Cenozoic. We aim to describe the main phases of that topographic evolution, but also to point out the remaining inconsistencies between the various observations and to provide ideas for further investigations of the Mesozoic topography of Central Asia.

\section{Synthesis of the available tectonic, geochronology, sedimentology and geomorphology data}

A summary of the main data discussed below is presented in Fig. 2.

\subsection{The Carboniferous - Permian evolution}

It is commonly admitted that the Palaeozoic construction of the Tian Shan lithosphere through accretion of various continents and arc terranes ended during the Carboniferous by the collision between two blocks: the Yili - Central Tian Shan block and the North Tian Shan volcano-sedimentary complex - Junggar block (Figs. 1 and 3a) (e.g. Han et al., 2009; Wang et al., 2009; Charvet et al., 2011; Xia et al., 2012). However, the modalities of that last accretion event are still discussed. Two contrasting types of models are proposed.

The first models imply that the Late Carboniferous - Early Permian lavas that are widely exposed in the Yili block were emplaced in a continental rift setting (e.g. Xiao et al., 1992; Che et al., 1996; Xia et al., 2004, 2008). Based on geochemical analysis and zircon $\mathrm{U} / \mathrm{Pb}$ dating of the various Early to Middle Carboniferous volcanics and ophiolite suites occurring in the North Tian Shan block and indicative of an oceanic domain, Xia et al. (2005) suggested that this North Tian Shan Ocean was a Early Carboniferous shortlived ocean which closed before Late Carboniferous generating the North Tian Shan Middle Carboniferous ophiolite suite. This closure was followed by post-orogenic extension and transtension associated to continental rift-type volcanism in the Yili, Turfan and associated basins during the Late Carboniferous - Permian.

These models have been challenged by a number of tectonic, stratigraphic and geochemical evidences. Wang et al. (2009) indicated that magmatism in the Tian Shan has been continuous from Early Carboniferous to Permian with a magma composition evolving from essentially calc-alkaline and seldom transitional during the Carboniferous to coexisting calc-alkaline, transitional and alkaline during the Permian. Hence, alternative models proposed that the Carboniferous magmas would have been generated during southward subduction of the North Tian Shan Ocean (in these models a branch of the wide Paleo-Asian Ocean) underneath the Yili block (e.g. Wang et al., 2006, 2009; Han et al., 2009; Charvet et al., 2011). The North Tian Shan ophiolite sequence would correspond to an accretionary wedge developed in front of a Carboniferous forearc. This subduction ended with the Late Carboniferous - Early Permian closure of the North Tian Shan Ocean and the collision between the Yili block and the North Tian Shan - Junggar blocks (e.g. Gao et al., 1998, Wang et al., 2006, Charvet et al., 2007, Shu et al., 2010; Charvet et al., 2011) (Figs. 2 and 3a). The Permian magmas were then emplaced in a post-collisional setting and several authors suggested that slab break-off and lithospheric delamination may explain their mantle signature (Han et al., 1999, 2009; Chen and Jahn, 2004; Zhao et al., 2008; Shu et al., 2010). By Late Carboniferous - Early Permian, the Junggar Basin, disconnected from the Palaeo-Tethys ocean (Sha et al., 2011), initiated as a half-graben structure in a post-collisional extensional setting (Qiu et al., 2005, 2008; Yang et al., 2012).

All the models agree that during the Permian, the Tian Shan area was affected by a major transtension episode (Fig. 3b). Palaeomagnetic data analyses indicate that between the Upper Carboniferous and the Middle Permian, the Yili - West Junggar collage rotated counter-clockwise by $46.2^{\circ} \pm 15.1^{\circ}$ with respect to the Tarim and $31.6^{\circ} \pm 15.1^{\circ}$ with respect to Siberia (Wang et al., 2007b). As those continental blocks were amalgamated during the Upper Carboniferous this rotation has been accommodated by strikeslip motion along large lithospheric faults such as the North Tian Shan Fault, the Main Tian Shan Shear Zone, the Narat Fault or the Nikolaev Line in Tian Shan or the Erqishi shear zone in the Altay (Fig. 1). The total amount of E-W lateral displacement between Siberia and the Tarim is estimated at 


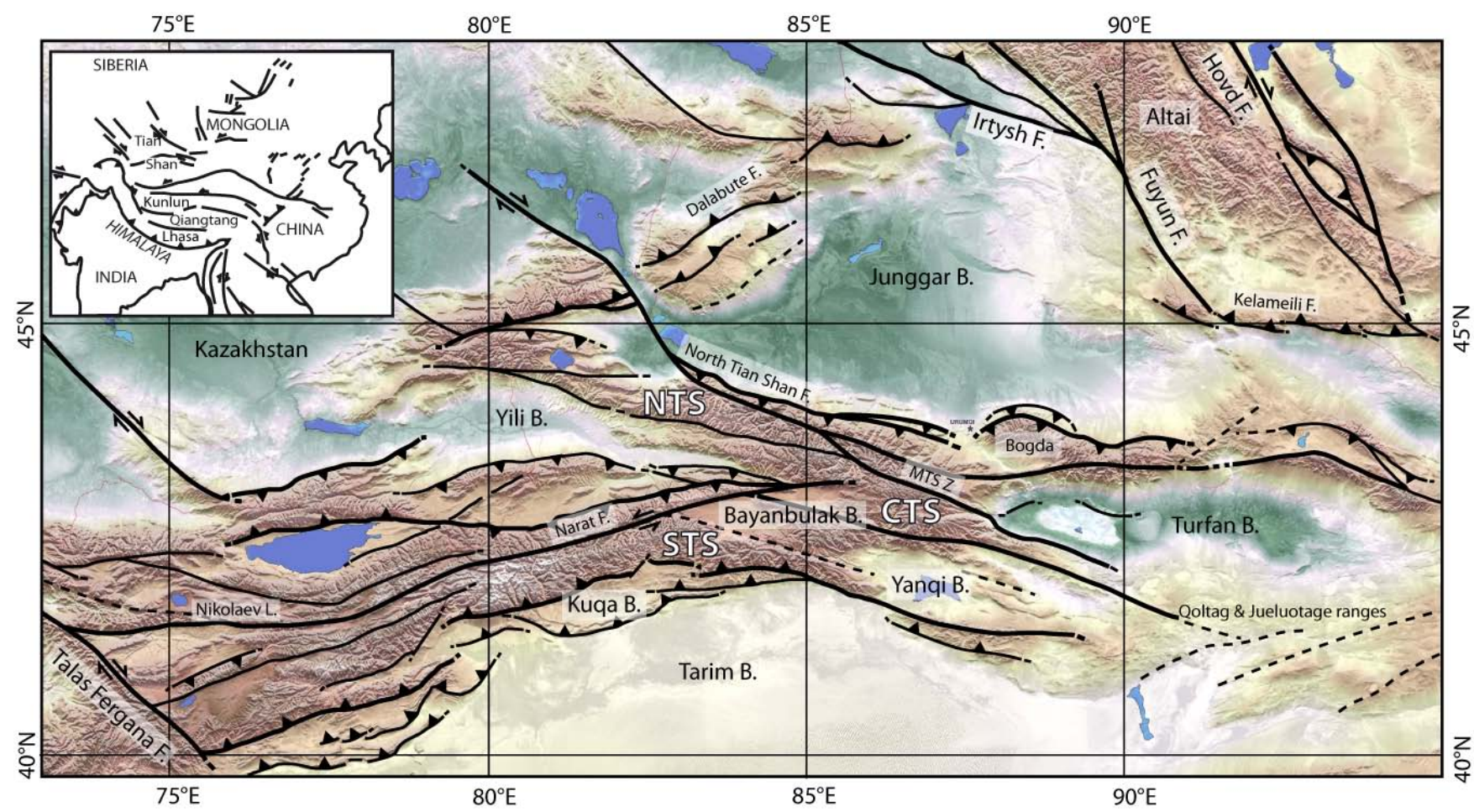

Fig. 1. General topographic and tectonic map of the Tian Shan Range and surrounding areas. MTS Z: Main Tian Shan Shear Zone; B. stands for basin; F. stands for fault. STS: South Tian Shan block. CTS: Central Tian Shan block. NTS: North Tian Shan block. The topography is a courtesy of S. Dominguez.

$1160 \pm 380 \mathrm{~km}$ (Wang et al., 2007b). Similar structures, like the Dalabute Fault to the west or the Kelameili Fault along the Altay, were also active around the Junggar Basin itself submitted to significant extension (e.g. Allen et al., 1991, 1995; Allen and Vincent, 1997; Qiu et al., 2005, 2008; Yang et al., 2012). Those large strike-slip faults have been active from Early Permian to Early Triassic (ca. 290-250 Ma; Laurent-Charvet et al., 2002; Shu et al., 2002; Wang et al., 2004, 2007a, de Jong et al., 2009) and partially controlled the emplacement of the Permian granitoids in Tian Shan (Wang et al., 2009). Zircon (U-Th)/He Permian ages indicate a strong cooling - exhumation phase within the Tian Shan Range at that time implying the build-up of a major positive topography affected by erosion (Jolivet et al., 2010) (Fig. 3b). Along the southern Junggar margin, detrital zircon $\mathrm{U} / \mathrm{Pb}$ analysis indicate a major source area in the North Tian Shan block associated to a widening of the drainage pattern towards the Central Tian Shan block (Yang et al., 2012), again suggesting the presence of significant reliefs. Pull-apart basins formed along those strike-slip fault zones, sometimes associated to volcanism as along the Dalabute Fault (Allen and Vincent, 1997) (Fig. 1). De Jong et al. (2009) suggested that the continental breakup regime that allowed the emplacement of the Late Permian - Early Triassic volcanic trapps in Siberia (Courtillot et al., 1999) could have generated a widespread extensive event within Central
Asia, reaching the Tian Shan area. South of the Bogda Shan and between the Tarim and South Tian Shan, extension allowed the formation of relatively small-scale but deep basins that connected with the close-by Palaeo-Tethys Ocean to the south (in the Tarim) and filled with Permian marine sediments (Li et al., 2005; Shu et al., 2010) (Fig. 3b). The occurrence of these sediments contrasts with the near absence of post-Carboniferous marine formations within the whole Altai - Junggar - Tian Shan area to the north that remained completely disconnected from any marine environment since the Early Permian. The Permian - Early Triassic closure of the Palaeo-Tethys and the subsequent Middle Triassic collision between the Qiangtang and Kunlun blocks to the south (Fig. 1) (e.g. Roger et al., 2008, 2010, 2011) might have ended that extension phase (e.g. Allen et al., 1991; Wartes et al., 2002; De Grave et al., 2007). In the Turfan area, sediments were then deposited in intra-mountain lacustrine and fluvial environments with a major sediment source from the Jueluotage Range to the south (Shao et al., 1999) (see Fig. 1 for location).

\subsection{Triassic - Jurassic evolution}

During the Early Triassic, the tectonic regime in the Tarim Tian Shan - Junggar area changed to become clearly compressive (Fig. 2). Apatite fission track data from the Tian 


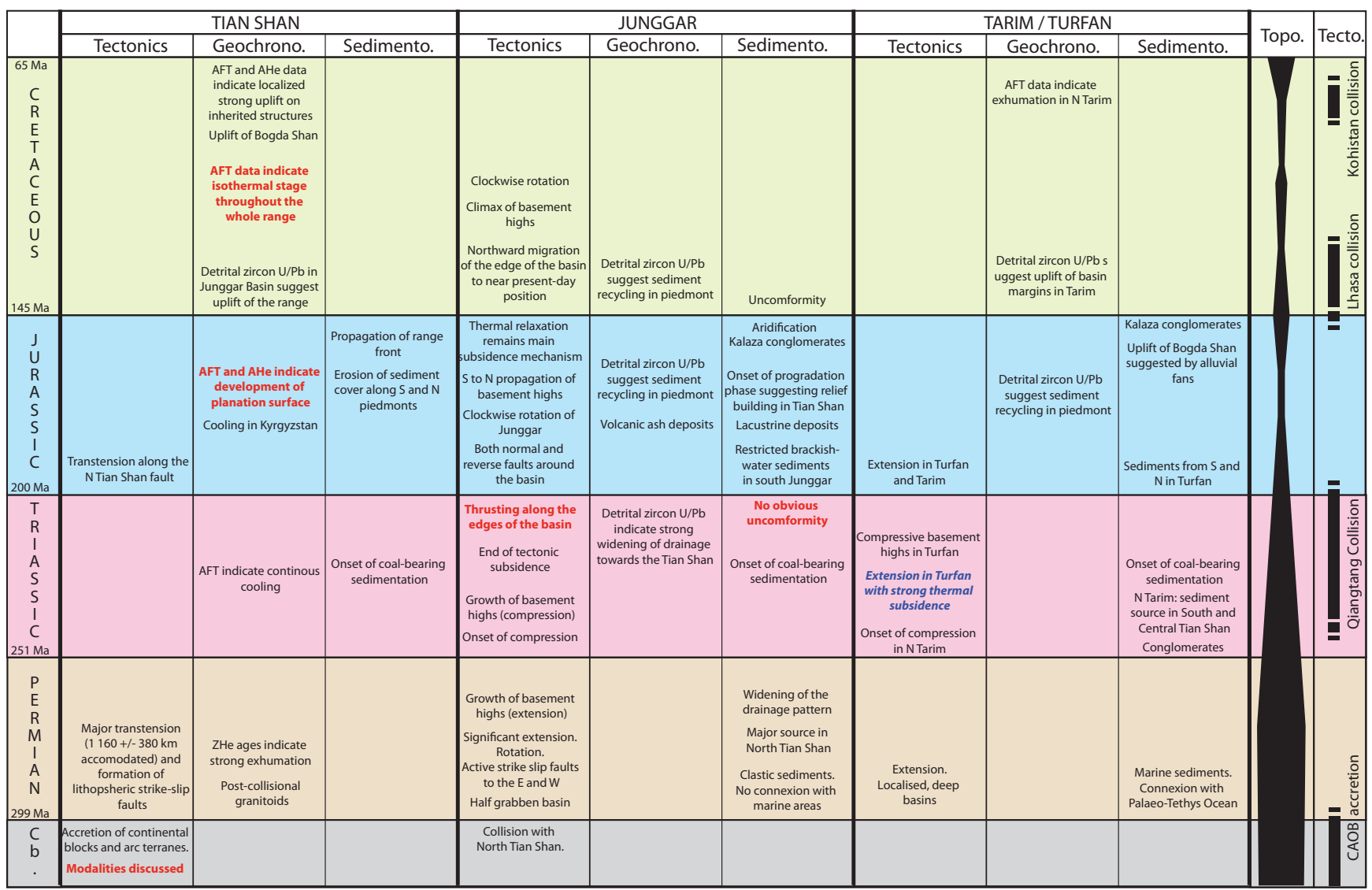

Fig. 2. Summary of the main Mesozoic tectonic, geochronological and sedimentological constrains in the Tian Shan Range and the Junggar and Tarim-Turfan basins. The data indicated in red are apparently in contradiction with the interpretation derived from other available data at the same time. The data in blue is contradicting the others but can be explained by local mechanisms. Column Topo. indicates the relative increase (wide black line) or decrease (thin black line) of the Tian Shan general topography. Column Tecto. recalls the major geodynamic events that affected Central Asia.

Shan clearly indicate a continuous cooling phase during the Triassic and Jurassic, even if the cooling rate become extremely slow during Middle to Late Jurassic (e.g. Dumitru et al., 2001; De Grave et al., 2007; Jolivet et al., 2010). Basement highs (imaged by seismic lines) that already started to uplift during the Carboniferous compressive (He et al., 2005) and Permian transpressive event in the western Junggar Basin continued to grow during the Triassic (Liu et al., 2006). However, within the Turfan Basin, tectonic extension still prevailed during the Early Triassic, associated to a strong thermal subsidence (Shao et al., 1999). Sediments were still derived from the south. In the northern Tarim Basin, south to southeasward directed palaeocurrents, as well as detrital zircon $\mathrm{U} / \mathrm{Pb}$ dating, indicate a sediment source in the Central Tian Shan block and along the southern margin of the South Tian Shan block (Li et al., 2004, Li and Peng, 2010). This, associated with the occurrence of Lower Triassic conglomerates in the Early Triassic Ehuobulake Formation of the Kuqa sub-basin (the names of the various sedimentary formations can be found for example in Hendrix et al., 1992, Shao et al., 1999; Jin et al., 2008 and Qiu et al., 2008), is consistent with the compression-related exhumation phase recognized by the low temperature thermochronology data within the range (Dumitru et al., 2001; Li et al., 2004; Jolivet et al., 2010). Detrital zircon U/Pb dating in the Middle to Late Triassic along the southern edge of the Junggar Basin (Xiaoquangou Group) indicate a strong widening of the drainage system towards the Central Tian Shan block associated to the progressive erosion of the Permian - Early Triassic topography (Yang et al., 2012). From Middle Triassic, basement highs also started to develop in the Turfan Basin, probably in a compressional setting (Shao et al., 1999). During the same period, tectonic subsidence ceased in the Junggar Basin, which became a slowly subsiding depression (Yang et al., 2012).

Except in the northern and western edges of the Junggar Basin, where Late Triassic thrusting occurred (Allen et al., 1991; Liu et al., 2006), and in the south Junggar, where small reverse movements took place (Yang et al., 2012), there is no obvious discordancy between the Upper Triassic and the 

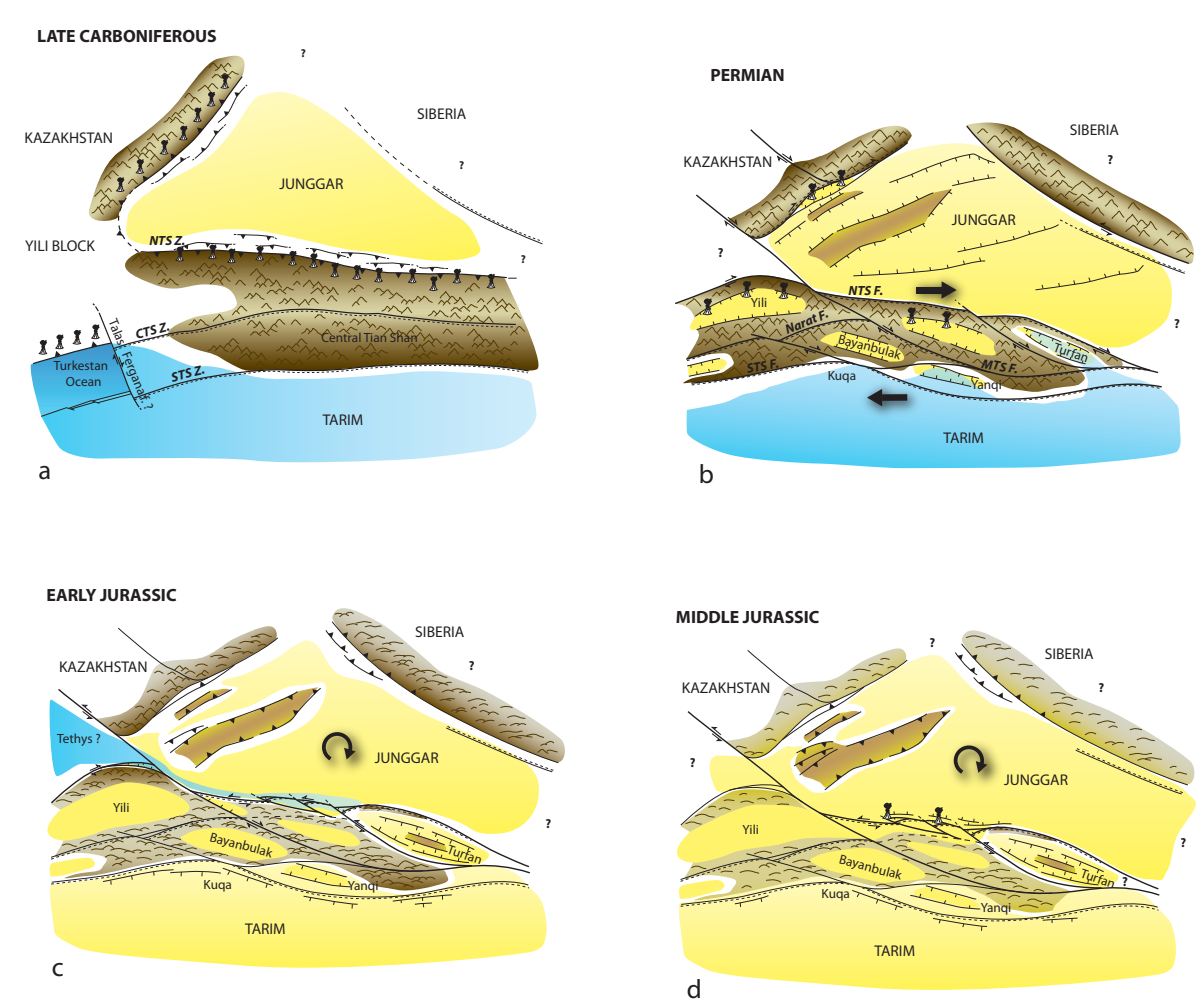

\section{LATE CRETACEOUS}

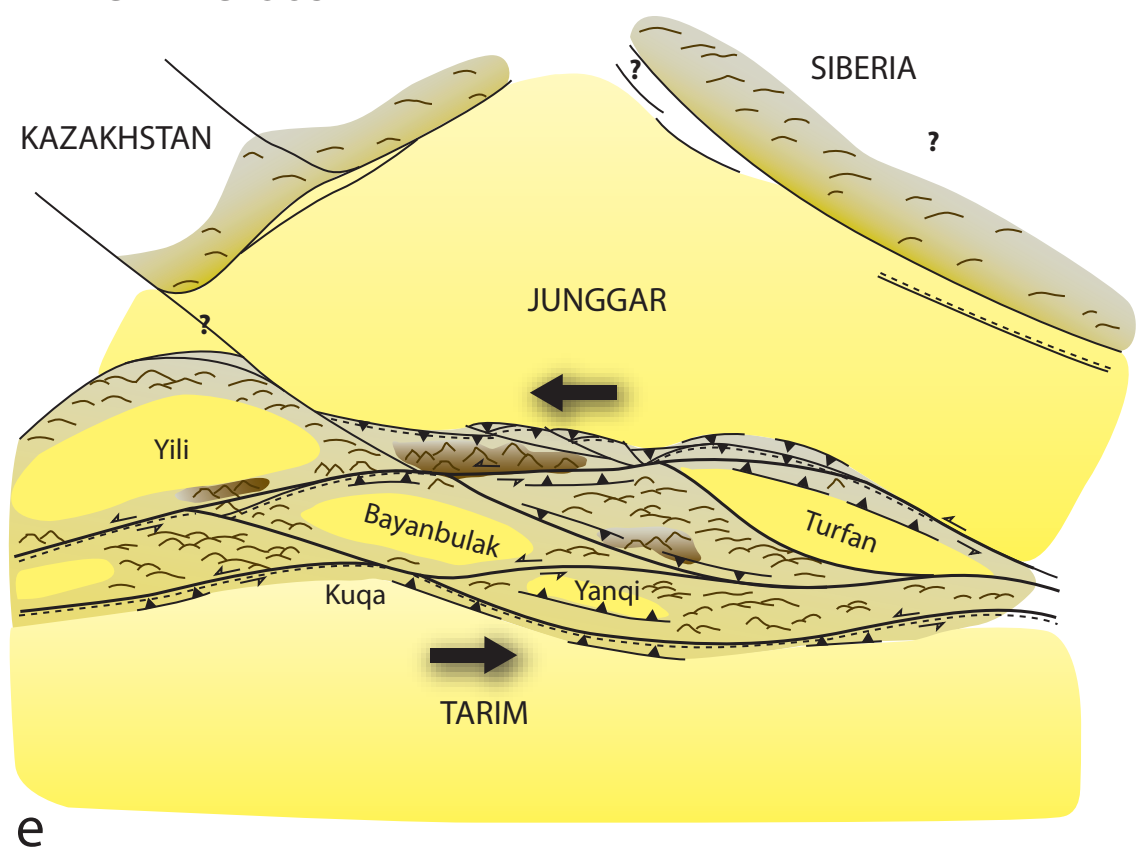

Fig. 3. Reconstitution of the main topographic pattern of the Tian Shan area through time. The brown areas correspond to mountains, the yellow areas to continental basins and the blue areas to marine basins. On Fig. 2a, NTS Z: North Tian Shan Shear Zone; CTS Z: Central Tian Shan Shear Zone; STS Z: South Tian Shan Shear Zone. See text for complete discussion. 
Lower Jurassic series (e.g. Sha et al., 2011). Indeed, from the Middle Triassic to the Middle Jurassic, a widespread coalbearing sediment sequence developed throughout the Tian Shan and surrounding basins, most probably in a warm humid climate (Hendrix et al., 1992; Pfretzschner et al., 2005; Li et al., 2004; Tükten et al., 2004; Ashraf et al., 2010; Pan et al., 2013.

During the same period, the relative topography between the range and the northern margin of the Tarim decreased while the Junggar Basin widened towards the south ( $\mathrm{Li}$ et al., 2004; Fang et al., 2005; Li and Peng, 2010; Yang et al., 2012). In Early Jurassic (Sinemurian Badaowan Fm.), a brackish-water fauna and flora (Waagenoperma bivalve assemblages and Tasmanites sp. alga) developed in some restricted areas along the southern margin of the Junggar Basin (Sha et al., 2011). Pan et al. (2013) suggested that small short-lived transtensional basins formed through reactivation of the North Tian Shan Fault. A contemporaneous increase in the water level of the North Tethys Ocean allowed a transgression event from the west along the southern margin of the Junggar (Fig. 3c). Small-scale tectonic activity, driven by a Jurassic - Early Cretaceous clockwise rotation of the Junggar block (Hou et al., 2009) is also observed in the northern and western Junggar during the Early and Middle Jurassic, both on thrust faults (Allen and Vincent, 1997) and normal faults (Liu et al., 2006). Seismic data interpretation indicates that this tectonic activity induced the uplift of topographic highs in the basin that propagated from south to north. However, the main driving mechanism for the subsidence of the Junggar basin would remain the thermal relaxation (Hou et al., 2009).

During the Early Jurassic (Badaowan Fm.), the Turfan Basin was also affected by extension that controlled its sedimentation during most of the Jurassic (Fig. 2). The sediments were still deposited in an environment influenced by surrounding topographic highs. Their main source area remained in the south (Qoltag and Jueluotage Ranges, Fig. 1), but small alluvial fans also formed on the northern edge of the basin, along the Bogda Shan. However, the topography of that range remained low (Shao et al., 1999, 2003). Normal faulting also affected the northern Tarim margin during the Jurassic (Allen et al., 1991).

By Middle Jurassic, a widespread planation surface started to develop over most of Central Asia, extending probably from Northern Tibet to SE Siberia (e.g. Allen et al., 2001; Vassallo et al., 2007b; Jolivet et al., 2007, 2009, 2010, 2013a). Remnants of that surface are still preserved in the central and northern part of the Tian Shan Range (e.g. Jolivet et al., 2010) (Fig. 3d). Over the same period, the apatite fission track data obtained from the central Chinese Tian Shan show a slow erosion period (isothermal to very slow cooling pattern compatible with a tectonically quiet phase) throughout the whole range (Dumitru et al., 2001; Jolivet et al., 2010; Glorie et al., 2010). However, further west in Kyrgystan, De Grave et al. (2007) indicate continuous cooling from
180 to $110 \mathrm{Ma}$. In the Junggar Basin, the long-lasting general retrogradation phase that initiated in the Late Carboniferous ended with the lacustrine facies of the Middle Jurassic Xishanyao Formation. The late Middle Jurassic change to a progradation phase suggests a renewed topography building in the Tian Shan or a strong climate change (Yang et al., 2012). However, the warm humid climate conditions that prevailed since Middle Triassic did not change until the onset of a strong aridification during the Late Jurassic (Qigu Formation) (Allen et al., 1991; Hendrix et al., 1992; Parrish, 1993; Shao et al., 2003; Li et al., 2004; Pan et al., 2013). Detrital zircons $\mathrm{U} / \mathrm{Pb}$ dating still suggest a wide drainage system encompassing the North Tian Shan and the Central Tian Shan blocks but local recycling of the Early Mesozoic cover may have also occurred (Yang et al., 2012). The Middle and Upper Jurassic series of the southern Junggar are also marked by the occurrence of widely distributed volcanic ashes of intracontinental basaltic composition interbedded within the sediments (Wang and Gao, 2012; Yang et al., 2012).

As previously said, the Late Jurassic period is marked by a strong aridification and the widespread occurrence of the conglomeratic Kalaza Formation in the Junggar, northern Tarim and Turfan basins (Fig. 2). In the south Junggar and north Tarim, conglomerates are derived from the Tian Shan Range while in the Turfan Basin, southward thinning of the Kalaza Formation from the northern edge of the basin indicates a source in the Bogda Shan then forming a topographic high (e.g. Hendrix et al., 1992, 2000; Shao et al., 1999; Sha et al., 2011). Detrital zircons U/Pb dating in the southern Junggar indicates, that recycling of the Mesozoic cover sequence associated to some topographic growth initiated during Middle Jurassic (Yang et al., 2012). In the Kuqa sub-basin, similar detrital zircons $\mathrm{U} / \mathrm{Pb}$ dating indicates a sediment source in the South Tian Shan where the sediment cover was progressively eroded. This front of the range progressively migrated towards the south, increasing the difference in topography between the basin and the uplifting range (Li et al., 2004).

Finally, at least in the Junggar Basin, the Lower Cretaceous series are described as unconformably lying on the Kalaza Formation (Sha et al., 2011), this again indicating a Late Jurassic tectonic activity (e.g. Hendrix et al., 1992, 2000; Shao et al., 1999; Sha et al., 2011). However, these tectonic movements are not or only poorly recorded by the low temperature thermochronology data in the central part of the Chinese Tian Shan (Dumitru et al., 2001; Jolivet et al., 2010). Contemporaneous cooling is only observed in the Kyrgyz Tian Shan further west (e.g. De Grave et al., 2007). Consequently, this near absence of cooling evidences in the low temperature thermochronology record, like the formation and the extensive preservation of the Jurassic planation surface within the range, are difficult to reconcile with Middle to Late Jurassic topographic growth and erosion revealed by the sedimentological and detrital zircon $\mathrm{U} / \mathrm{Pb}$ data. 


\subsection{Cretaceous - Early Palaeogene evolution}

Sediment analysis and detrital zircon $\mathrm{U} / \mathrm{Pb}$ dating indicate that tectonic uplift continued during the Early Cretaceous along the southern edge of the Junggar Basin (Fang et al., 2006; Yang et al., 2012). An increase in the amount of detrital zircons derived from the North Tian Shan block suggests a noticeable uplift and denudation of this block. This uplift potentially formed a barrier to the sediments coming from further south. The southern edge of the basin was slightly uplifted and migrated northward to approximately its presentday position (Fang et al., 2006). The clockwise rotation of the Junggar block continued and intra-basin highs, which initiated during the Jurassic, reached their climax in Early Cretaceous with relative topographies up to $600 \mathrm{~m}$ based on erosion surfaces imaged by seismic data (Hou et al., 2009). A similar basin margin uplift is observed in the north Tarim Basin margin. Indeed, detrital zircon $\mathrm{U} / \mathrm{Pb}$ analysis indicate an increase in denudation of the Central Tian Shan and South Tian Shan blocks associated to an increase of the differential topography between the basin and the range (Li and Peng, 2010).

Several authors suggested that the Early Cretaceous deformation around the Tian Shan Range resulted from the collision of the Lhasa block to the south (Figs. 1 and 2) (e.g. Hendrix et al., 1992; Gu, 1996; Fang et al., 2006a; De Grave et al., 2007). However, the absence of Late Jurassic - Early Cretaceous cooling episode in the Songpan Garze area (East Tibet), immediately north of the Bangong - Nujiang suture Zone between the Lhasa and Qiangtang blocks suggests that this accretion generated only a very limited deformation (Coward et al., 1988; Roger et al., 2008, 2010, 2011). Nonetheless, further to the north, between the Kunlun Ranges and the Tarim Basin, low temperature thermochronology and sediment analysis do indicate some small-scale Cretaceous vertical movements potentially linked to the Lhasa collision (e.g. Vincent and Allen, 1999; Jolivet et al., 1999, 2001; Marshallsea et al., 2000). Within the Chinese part of the Tian Shan Range, the low temperature thermochronology data indicate that the near isothermal stage that started during the Middle Jurassic still prevailed during the Cretaceous (e.g. Jolivet et al., 2010). In Kyrgystan, this phase is also recorded from late Early Cretaceous up to the Palaeogene (e.g. De Grave et al., 2007; Glorie et al., 2010). As for the Middle and Late Jurassic, this contradicts the sedimentological (occurrence of conglomerates in the Cretaceous series) as well as recycling observed in the detrital zircon U/Pb data. However, Zhang et al. (2009), using apatite fission track analysis, reported evidences of Late Cretaceous exhumation near Aksu, along the northern margin of the Tarim Basin.

Eventually, the late Late Cretaceous - Early Palaeogene marks the onset of a new deformation phase that will culminate with the ongoing orogeny (Figs. 2 and 3e). Within the range, the low temperature thermochronology data show that localized and rapid deformation and uplift occurred as early as 65 to $60 \mathrm{Ma}$ on large inherited structures such as the Nikolaev line (Jolivet et al., 2010). Apatite fission track analysis in the Bogda Shan Range also show an onset of cooling and uplift around $65 \mathrm{Ma}$ (Wang et al., 2008). The geodynamic mechanism driving those localized, Early Cenozoic deformations is still poorly known and might correspond either to far-field effects of the closure of the Mongol-Okhotsk Ocean in SE Siberia (Wang et al., 2008; Jolivet et al., 2009, 2010) or to terranes accretions such as the Kohistan-Dras Arc or the Kabul Block to the west in Afghanistan and northwestern Pakistan (Searle, 1991; Hendrix et al., 1992; Jolivet et al., 2010).

\section{Discussion}

Many evidences - tectonic, geochemical, geochronological and sedimentological - are in favour of the Late Carboniferous subduction - collision model (e.g. Gao et al., 1998, Wang et al., 2006, Charvet et al., 2007, Shu et al., 2010; Charvet et al., 2011). While the alternative rift model (e.g. Xiao et al., 1992; Che et al., 1996; Xia et al., 2004, 2008) would have generated a relatively low-relief topography distributed over most of the present day Chinese Tian Shan area, the subduction - collision model probably gave birth to a dissected, high relief, Andean- to Alpine-type topography (Fig. 3a). This kind of topography is consistent with the Late Palaeozoic Early Mesozoic erosion of metamorphic basement rocks (e.g. Yang et al., 2012).

The Permian transtension event and the formation of large pull-apart basins along major strike-slip faults was certainly one of the main tectonic events in the geodynamic history of the range. The Late Carboniferous - Early Permian collisionrelated topography was dissected as strike-slip motion created the Yili, Bayanbulak, and Turfan basins. This event set up the tectonic framework of the Mesozoic and Tertiary Tian Shan (Fig. 3b). Continuous tectonic and/or thermal subsidence prevailed in the Junggar Basin during all that period. It was possibly linked to the general extensional setting that affected the northern part of Central Asia (De Jong et al., 2009), and allowed the deposition and preservation of the sediments issued from the widespread denudation of the adjacent areas as recorded by the low temperature thermochronology data (e.g. Dumitru et al., 2001; Jolivet et al., 2010).

The onset of renewed compression marked by basin inversion and basement cooling during the Early Triassic marks the end of the strike-slip phase (e.g. Dumitru et al., 2001; Liu et al., 2006; Jolivet et al., 2010). This Early Triassic event, probably linked to the final closure of the Palaeo-Tethys Ocean to the south (e.g. Roger et al., 2008, 2010, 2011), was followed by a general decrease in relief and the progressive formation of the flat topography that will characterize Central Asia during the Mesozoic. Local extension such as in the 
Turfan Basin and thermal subsidence in the Junggar Basin maintained active sedimentation areas filled with sediments derived from erosion of remaining topographic highs.

Except for the development of basement highs within the Junggar Basin, flattening of the topography further continued during the Early and Middle Jurassic. The development of a flat topography is consistent with the widespread occurrence of a coal system throughout the whole area (e.g. Sha et al., 2011) (Figs. 3c and 2d). The relief between the Tian Shan area and the surrounding basins probably decreased through erosion. This phase of slow erosion is clearly recorded by the low temperature data that show a protracted isothermal stage during the whole Jurassic period (e.g. Dumitru et al., 2001; Jolivet et al., 2010; Glorie et al., 2010). However, tectonic activity probably still occurred along some of the major Permian tectonic structures, creating reliefs. For example, the formation of small-scale extensional (probably pullapart) basins along the southern edge of the Junggar Basin, associated with volcanism, suggest strike-slip faulting along the North Tian Shan Fault zone (Pan et al., 2013). Evidence for local relief building is further attested by the observed, progressive recycling of the Mesozoic sediments along the southern margin of the Junggar (Yang et al., 2012). However, topographic highs were certainly not important and the peneplanation phase probably reached its maximum during the Middle or Late Jurassic like in most of Central Asia (e.g. Vassallo et al., 2007b; Jolivet et al., 2001, 2007).

The occurrence of the major alluvial fan system of the Late Jurassic Kalaza Formation seems to mark the onset of a new tectonic and topographic phase. While the low temperature thermochronology data obtained on basement rocks in the Chinese Tian Shan still indicate slow, erosion-driven cooling (Dumitru et al., 2001; Jolivet et al., 2010), sedimentological and tectonic evidences imply tectonic changes of topography. The Late Jurassic period is also marked by aridification (Allen et al., 1991; Hendrix et al., 1992; Parrish, 1993; Shao et al., 2003; Pan et al., 2013). The formation of the Kalaza alluvial fan could be linked to this climate change but relief building is also attested by the uncomformity between the Late Jurassic and Lower Cretaceous sediments in the Tarim and Junggar basins (e.g. Hendrix et al., 1992, 2000; Shao et al., 1999; Sha et al., 2011). Similarly, Late Jurassic - Early Cretaceous basement cooling observed in the Kyrgyz Tian Shan suggest tectonic activity (De Grave et al., 2007). Altogether this tectonic phase remains poorly understood. Once again, relief building during that period must have been limited both in magnitude and extend. Widespread formation of relief is not compatible with the preservation - up to now - of the Mesozoic planation surface within the range. It has been suggested that the deformation observed in the Tian Shan was linked to the Early Cretaceous collision between the Lhasa block and the southern margin of Eurasia (e.g. Hendrix et al., 1992; Gu, 1996; Fang et al., 2006; De Grave et al., 2007). However, if the Late Jurassic Kalaza Formation marks the onset of the tectonic phase, it initiated prior to the colli- sion. Furthermore this collision generated only a very limited amount of deformation and exhumation along the southern margin of the Qiangtang block (e.g. Coward et al., 1991; Roger et al., 2008, 2010, 2011). Why then did this collision affect the Central Asian crust several thousands of kilometers to the north? Another major geodynamic event, the closure of the Mongol-Okhotsk Ocean, affected Central Asia during the Mesozoic (e.g. Zonenshain et al., 1990a, b; Nie et al., 1990; Zorin et al., 1990; Metelkin et al., 2007, 2010). While the age of the final closure is still largely discussed (see Jolivet et al., 2009, 2013b and references therein), it probably occurred during the Cretaceous in southern Siberia. The farfield effects of that oceanic closure (combined or not with the effects of the Lhasa collision) could also be the driving mechanism for the Late Mesozoic deformations in the Tian Shan area.

Finally, the Late Cretaceous - Early Palaeogene reactivation of the Palaeozoic (mainly Permian) major strike-slip structures initiated the building of the present day Tian Shan topography (Fig. 3e). The relief first formed in highly localized zones along strike-slip faults like the Narat Fault (Jolivet et al., 2010). The preservation of large remnants of the Mesozoic planation surface implies that exhumation and erosion within the present day Tian Shan is still low and remains localized along discrete inherited tectonic structures.

\section{Conclusions}

The Late Palaeozoic and Mesozoic topographic evolution of the Tian Shan Range has been controlled by two, very different mechanisms:

- During the Late Carboniferous - Early Permian, oceans are still present around the Palaeo-Tian Shan and the topography is controlled by subduction and collision events. This probably first generated an Andean-type topography followed by an Alpine-type topography after the final closure of the Palaeo-Asian Ocean.

- After this final oceanic closure and up to now, the Tian Shan became an intra-continental area, only affected by the far field effects of continental collisions and oceanic closures that happened several thousands of kilometers away. During this second phase, the Middle-Permian - Early Palaeogene topographic evolution has been marked by the Middle to Late Permian dislocation of the Late Carboniferous relief and its progressive planation.

Indeed, several small-scale tectonic deformations affected the Tian Shan area during the Mesozoic. However the associated topographic changes remained limited and probably localized. While the Cimmerian collisions certainly induced the Triassic compressive event that ended the major 
Permian strike-slip movements, the Late Jurassic and Cretaceous phase is still poorly understood. If the Cretaceous collision of the Lhasa block might have generated some of the stress that induced Late Mesozoic deformation in the Tian Shan, the effects of the Mesozoic closure of the MongolOkhotsk ocean should also be considered.

Finally, the synthesis of all the available data, and especially the discrepancy between the low temperature thermochronology data and the sedimentology data during the Late Mesozoic period demonstrates the need of combining both methods to decipher in details the topographic evolution of a region.

Acknowledgements. This work was supported by the DARIUS and INSU SYSTER programs. This is IPGP contribution 3369.

Edited by: F. Métivier and Z. Dong

Reviewed by: two anonymous referees

\section{References}

Allen, M. B., Windley, B. F., Zhang, C., Zhao, Z. Y., and Wang G. R.: Basin evolution within and adjacent to the Tienshan range, NW China, J. Geol. Soc. Lond., 148, 369-378, 1991.

Allen, M. B., Sengör, A. M. C., and Natal'in, B. A.: Juggar, Turfan and Alakol basins as Late Permian to Early Triassic extensional structures in a sinistral shear zone in the Altaid orogenic collage, Central Asia, J. Geol. Soc. Lond., 152, 327-338, 1995.

Allen, M. B. and Vincent, S. J.: Fault reactivation in the Junggar region, northwest China: the role of basement structures during Mesozoic-Cenozoic compression, J. Geol. Soc. Lond., 154, 151155, 1997.

Allen, M. B., Aslop, G. I., and Zhemchuzhnikov, V. G.: Dome and basin refolding and transpressive inversion along the Karatau fault system, southern Kazakstan. J. Geol. Soc. Lond., 168, 8395, 2001.

Ashraf, A. R., Sun, Y., Uhl, D., Mosbrugger, V., Li, J., and Herrmann, M.: Triassic and Jurassic palaeoclimate development in the Junggar Basin, Xinjiang, Northwest China: a review and additional lithological data. Palaeobiol. Palaeoenviron., 90, 187201, 2010.

Batt, G. E. and Braun, J.: The tectonic evolution of the Southern Alps, New Zealand: insights from fully thermally coupled dynamical modelling, Geophys. J. Int., 136, 403-420, 1999.

Bookhagen, B. and Burbank, D.W.: Topography, relief, and TRMM-derived rainfall variations along the Himalaya, Geophys. Res. Lett., 33, L08405,doi:10.1029/2006GL026037, 2006.

Charvet, J., Shu, L. S., and, Laurent-Charvet S.: Paleozoic structural and geodynamic evolution of eastern Tianshan (NW China): Welding of the Tarim and Junggar plates, Episodes, 30, 162-186, 2007.

Charvet, J., Shu, L.-S., Laurent-Charvet, S., Wang, B., Faure, M., Cluzel, D., Chen, Y., and De Jong, K.: Palaeozoic tectonic evolution of the Tianshan belt, NW China, Science China, Earth Sci., 54, 166-184, 2011.
Che, Z. C., Liu, L., Liu, H. F., and Luo, J. H.: Review on the ancient Yili rift, Xinjiang, China, Acta Petrol. Sin., 12, 478-489, 1996. (in Chinese with English abstract)

Chen, B. and Jahn, B. M.: Genesis of post-collisional granitoids and basement nature of the Junggar terrane, NW China: Nd-Sr isotope and trace element evidence. J. Asian Earth Sci., 23, 691703, 2004.

Courtillot, V., Jaupart, C., Manighetti, I., Tapponnier, P., and Besse, J.: On causal links between flood basalts and continental breakup, Earth Planet. Sci. Lett., 166, 177-195, 1999.

Coward, M. P., Kidd, W. S. F., Pan, Y., Shackleton, R. M., and Zhang, H.: The structure of the 1985 Tibet Geotrverse, Lhasa to Golmud, Philos. T. R. Soc. S-A, 327, 307-336, 1988.

De Grave, J., Buslov, M. M., and Van Den Haute, P.: Distant effects of India-Eurasia convergence and Mesozoic intracontinental deformation in Central Asia : Constraints from apatite fission-track thermochronology, J. Asian Earth Sci., 29, 188-204, 2007,

De Jong, K., Wang, B., Faure, M., Shu, L. S., Cluzel, D., Charvet, J., Ruffet, G., and Chen, Y.: New 40Ar/39Ar age constraints on the Late Palaeozoic tectonic evolution of the western Tianshan (Xinjiang, northwestern China), with emphasis on Permian fluid ingress, Int. J. Earth Sci., 98, 1239-1258, 2009.

Dumitru, T. A., Zhou, D., Chang, E. Z., and Graham, S. A.: Uplift, exhumation, and deformation in the Chinese Tian Shan, Geol Soc. America Memoir, 194, 71-99, 2001,

Fang, S. H., Guo, Z. J., Song, Y., Wu, C. D., Zhang, Z. C., Wang, M. N., and Fan, R. D.: Sedimentary facies evolution and basin pattern of the Jurassic in southern margin area of Junggar Basin, J. Palaeogeogr., 7, 347-356, 2005. (in Chinese with English abstract)

Fang, S. H., Guo, Z. J., Wu, C. D., Zhang, Z. C., Wang, M. N., and Yuan, Q. D.: Jurassic clastic composition in the southern Junggar Basin, Northwest China: implications for basin-range pattern and tectonic attributes. Acta Geologica Sinica, 80, 196-209, 2006. (in Chinese with English abstract)

Gao, J., Li, M., Xiao, X., Tang, Y., and He, G.: Paleozoic tectonic evolution of the Tianshan orogen, northwestern China. Tectonophysics, 287, 213-231, 1998.

Glorie, S., De Grave, J., Buslov, M. M., Elburg, M. A., Stockli, D. F., Gerdes, A., and Van den haute, P.: Multi-method chronometric constraints on the evolution of the Northern Kyrgyz Tien Shan batholith (Central Asian Orogenic Belt): from emplacement to exhumation, J. Asian Earth Sci., 38, 131-146, 2010.

Gu, J. Y.: Characteristics of Sequence Stratigraphy and Sedimentary Evolution of Tarim Basin, Northwest China. Petroleum Industry Press, Beijing, 8-9, 206-225, 1996. (in Chinese)

Han, B. F., He, G. Q., and Wang, S. G.: Postcollisional mantlederived magmatism, underplating and implications for the bassement of the Junggar Basin, Science in China, Earth Sci., 42, 113 119, 1999.

Han, B.-F., Guo, Zh.-J., Zhang, Zh.-C., Zhang, L., Chen, J.-F., and Song, B.: Age, geochrmistry, and tectonic implications of a late Paleozoic stitching pluton in the North Tian Shan suture zone, western China, Geol. Soc. Am. Bull., 122, 627-640, 2009.

He, D. F., Zhai, G. M., Kuang, J., Zhang, Y., and Shi, X.: Distribution and tectonic features of paleo uplifts in the Junggar Basin, Chinese J. Geol., 40, 248-261, 2005.

Hendrix, M. S.: Evolution of Mesozoic sandstone compositions, southern Junggar, northern Tarim, and western Turpan basins, 
nortwestern China: a detrital record of the ancestral Tian Shan, J. Sediment. Res., 70, 520-532, 2000.

Hendrix, M., Graham, S. A., Carroll, A., Sobel, E., McKnight, C., Schulein, B., and Wang, Z.: Sedimentary record and climatic implications of recurrent deformation in the Tian Shan : Evidence from Mesozoic strata of the north Tarim, south Dzungar, and Turpan basin, northwest China. Geol. Soc. Am Bull., 104, 53-79, 1992.

Hou, L., Wang, J., Kuang, L., Zhang, G., Liu, L., and Kuang, J.: Provenance Sediments and its Exploration Significance - A Case from Member 1 of Qingshuihe Formation of Lower Cretaceous in Junggar Basin, Earth Sci. Front., 16, 337-348. 2009.

Jin, Zh., Yang, M., Lu, X., Sun, D., Tang, X., Peng, G., and Lei, G.: The tectonics and petroleum system of the Qiulitagh fold and thrust belt, northern Tarim basin, NW China, Mar. Petrol. Geol., 25, 767-777, 2008.

Jolivet, M., Roger, F., Arnaud, N., Brunel, M., Tapponnier, P., and Seward, D.: Histoire del'exhumation de l'Altun Shan : indications sur l'âge de la subduction du bloc du Tarim sous le système de l'Altyn Tagh (Nord Tibet),. C. R. Acad. Sci., 329, 749-755, 1999.

Jolivet, M., Brunel, M., Seward, D., Xu, Zh., Yang, J., Roger, F., Tapponnier, P., Malavieille, J., Arnaud, N., and Wu, C.: Mesozoic and Cenozoic tectonics of the northern edge of the Tibetan plateau: fission-track constraints, Tectonophysics, 343, 111-134, 2001.

Jolivet, M., Ritz, J.-F., Vassallo, R., Larroque, C., Braucher, R., Todbileg, M., Chauvet, A., Sue, C., Arnaud, N., De Vicente, R., Arzhanikova, and A., and Arzhanikov, S.: The Mongolian summits: An uplifted, flat, old but still preserved erosion surface, Geology, 35, 871-874, 2007.

Jolivet, M., De Boisgrollier, T., Petit, C., Fournier, M., Sankov, V. A., Ringenbach, J.-C., Byzov, L., Miroshnichenko, A.I., Kovalenko, S. N., and Anisimova, S. V.: How old is the Baikal Rift Zone? Insight from apatite fission track thermochronology, Tectonics, 28, TC3008, doi:10.1029/2008TC002404, 2009.

Jolivet, M., Dominguez, S., Charreau, J., Chen, Y., Li, Y., and Wang, Q.: Mesozoic and Cenozoic tectonic history of the Central Chinese Tian Shan: Reactivated tectonic structures and active deformation, Tectonics, 29, TC6019, doi:10.1029/2010TC002712, 2010.

Jolivet, M., Arzhannikov, S., Arzhannikova, A., Chauvet, A., Vassallo, R., and Braucher, R.: Geomorphic Mesozoic and Cenozoic evolution in the Oka-Jombolok region (East Sayan ranges, Siberia), J. Asian Earth Sci., doi:10.1016/jseaes.2011.09.017, 2013a.

Jolivet M., Arzhannikov, S., Chauvet, A., Arzhannikova, A., Vassallo, R., Kulagina, N., and Akulova, V.: Accomodating largescale intracontinental extension and compression in a single stress-field : a key example from the Baikal Rift System, Gondwana Res., 24, 918-925, 2013 b.

Juez-Larré, J., Kukowski, N., Dunai, T. J., Hartley, A. J., and Andriessen, P. A. M.: Thermal and exhumation history of the Coastal Cordillera arc of northern Chile revealed by thermochronological dating, Tectonophysics, 495, 48-66, 2010.

Laurent-Charvet, S., Charvet, J., Shu, L. S., Ma, R. S., and Lu, H. F.: Palaeozoic late collisional strike-slip deformations in Tianshan and Altay, eastern Xinjiang, NW China, Terra Nova, 14, 249256, 2002.
Li, X., Zhao, K., Dodson, J., and Zhou, X.: Moisture dynamics in central Asia for the last 15 kyr: new evidence from Yili Valley, Xinjiang, NW China, Quat. Sci. Rev., 30, 3457-3466, 2011.

Li, Y. J., Sun, L. D., Wu, H. R., Wang, G. L., Yang, C. S., and Peng, G. X.: Permo-Carboniferous radiolaria from the Wupatarkan Group, west terminal of Chinese South Tianshan, China J. Geol., 40, 220-226, 2005. (in Chinese with English abstract)

Li, Zh., Song, W., Peng, S., Wang, D., and Zhang, Zh.: MesozoicCenozoic tectonic relationships between the Kuqa subbasin and Tian Shan, northwest China: constraints from depositional records; Sediment. Geol., 172, 223-249, 2004.

Li, Zh. and Peng, S.: Detrital zircon geochronology and its provenance implications: responses to Jurassic through Neogene basin-range interactions along northern margin of the Tarim Basin, Northwest China, Basin Res., 22, 126-138, 2010.

Liu, H., Wang, Y., Xin, R., and Wang, Y.: Study on the slope break belts in the Jurassic down-warped lacustrine basin in westernmargin area, Junggar Basin, northwestern China, Mar. Petrol. Geol., 23, 913-930, 2006.

Liu-Zheng, J., Tapponnier, P., Gaudemer, Y., and Ding, L.: Quantifying landscape differences across the Tibetan plateau: Implications for topographic relief evolution. J. Geophys. Res., 113, F04018, doi:10.1029/2007JF000897, 2008.

Marshallsea, S. J., George, A. D., Wyrwoll, K. H., Chen, J., and Lu, Y.: Mid Miocene cooling in Hexi corridor - Qilian Shan region, Qinghai - Tibet plateau. 9th International Conference on Fission Track Dating and Thermochronology, Melbourne, Australia, 2000.

Metelkin, D. V., Gordienko, I. V., and Klimuk, V. S.: Paleomagnetism of Upper Jurassic basalts from Transbaikalia: new data on the time of closure of the Mongol-Okhotsk Ocean and Mesozoic intraplate tectonics of Central Asia, Russian Geol. Geophys., 48, 825-834, 2007.

Metelkin, D. V., Vernikovsky, V. A., Kazansky, A. Y., and Wingate, M. T. D.: Late Mesozoic tectonics of Central Asia based on paleomagnetic evidence, Gondwana Res., 18, 400-419, 2010.

Métivier, F. and Gaudemer, Y. : Mass transfer between eastern Tien Shan and adjacent basins (central Asia): constraints on régional tectonics and topography, Geophys. J. Int., 128, 1-17, 1997.

Molnar, P. and England, P.: Late Cenozoic uplift of mountain ranges and global climatic change: chicken or egg?, Nature, 346, 29-34, 1990.

Molnar, P., Boos, W.R., and Battisti, D.S.: Orographic Controls on Climate and Paleoclimate of Asia: Thermal and Mechanical Roles for the Tibetan Plateau, Annu. Rev. Earth Planet. Sci., 38, 77-102, 2010.

Nie, S., Rowley, D. B., and Ziegler, A. M.: Constraints on the location of Asian microcontinents in Paleo-Tethys during Late Palaeozoic, in: Palaeozoic Palaeogeography and Biogeographyedited by: McKerrow, W. S. and Scotese C. R., Geol. Soc. Mem. Am., 12, 12397-12409, 1990.

Nissen, E., Walker, R., Molor, E., Fattahi, M., and Bayasgalan, A.: Late Quaternary rates of uplift and shortening at Baatar Hyarhan (Mongolian Altai) with optically stimulated luminescence. Geophys. J. Int., doi:10.1111/j.1365-246x.2008.04067.x, 2009.

Pan, Y., Sha, J., Wang, Y., Zhang, X., Yao, X., Peng, B., and Rao, X.: The brackish-water bivalve Waagenoperna from the Lower jurassic Badaowan Formation of the Junggar Basin and its palaeoenvi- 
ronmental and palaeogeographic significance. Geoscience Frontiers, 4, 95-103, 2013.

Parrish, J. T.: Jurassic climate and oceanography of the circumPacific region, in: The Jurassic of the circum-Pacific, International Geological Correlation Programme Project 171G. edited by: Westermann, E.G., New York, Cambridge University Press, 365-379, 1993,

Pfretzschner, H.-U, Martin, T., Maisch, M. W., Matzke, A. T., and Sun, G.: A new docodont mammal from the Late Jurassic of the Junggar Basin in Northwest China, Ac. Palaeontol. Pol., 50, 799808, 2005.

Qiu, N. S., Zha, M., Wang, X. L., and Yang, H. B.: Tectono-thermal evolution of the Junggar Basin, NW China: constraints from Ro and apatite fission track modelling, Petrol. Geosci., 11, 361-372, 2005.

Qiu, N. S., Zhang, Z. H., and Xu, E. S.: Geothermal regime and Jurassic source rock maturity of the Junggar Basin, north-west China, J.Asian Earth Sci., 31, 4-6, 2008.

Ramstein, G., Fluteau, F., Besse, J., and Joussaume, S.: Effect of orogeny, plate motion and land-sea distribution on Eurasian climate change over the past 30 million years, Nature, 386, 788795, 1997.

Raymo, M. E. and Ruddiman, W. F.: Tectonic forcing of late Cenozoic climate. Nature, 359, 117-122, 1992.

Roger, F., Jolivet, M., and Malavieille, J.: Tectonic evolution of the Triassic fold belts of Tibet, Comptes Rendus Géosciences, 340, 180-189, 2008.

Roger, F., Jolivet, M., and Malavieille, J.: The tectonic evolution of the Songpan Garzê (North Tibet) and adjacent areas from Proterozoic to Present: a synthesis. J. Asian. Earth Sci., 39, 254-269, 2010.

Roger, F., Jolivet, M., Cattin, R., and Malavieille, J.: MesozoicCenozoic tectonothermal evolution of the eastern part of the Tibetan plateau (Songpan-Garzê, Longmen Shan area): insights from thermochronological data and simple thermal modeling. Geol. Soc. London Spec. Pub., 353, 9-25, 2011.

Searle, M. P.: Geology and Tectonics of the Karakorum Mountains. Wiley, New York, 358p., 1991.

Sha, J. G., Vajda, V., Pan, Y. H., Larsson, L., Yao, X. G., Zhang, X. L., Wang, Y. Q., Cheng, X. S., Jinag, B. Y., Deng, S. H., Chen, S. W., and Peng, B.: The Stratigraphy of Triassic-Jurassic boundary successions of southern margin of Junggar Basin, northwestern China, Ac. Geol. Sin., 85, 421-436, 2011.

Shao, L., Stattegger, K., Li, W., and Haupt, B. J.: Depositional style and subsidence history of the Turpan Basin (NW China), Sedimentary Geol., 128, 155-169, 1999.

Shao, L., Zhang, P., Hilton, J., Gayer, R., Wang, Y., Zhao, C., and Luo, Zh.: Paleoenvironments and paleogeography of the Lower and lower Middle Jurassic coal measures in the Turpan-Hami oilprone coal basin, northwestern China, AAPG. Bulletin, 87, 335$355,2003$.

Shu, L. S., Charvet, J., Lu, H. F., and Laurent-Charvet, S.: Paleozoic accretion-collision events and kinematics of ductile deformation in the central-southern Tianshan Belt, China, Ac. Geol. Sin., 76, 308-323, 2002

Shu, L.S., Wang, B., Zhu, W., Guo, Zh., Charvet, J., and Zhang, Y.: Timing of initiation of extension in the Tianshan, based on structural, geochemical and geochronological analyses of bimodal volcanism and olistostrome in the Bogda Shan (NW China), Int. J. Earth Sci., doi:10.1007/s00531-010-0575-5, 2010.

Sobel, E. R. and Strecker, M. R.: Uplift, exhumation and precipitation: tectonic and climatic control of Late Cenozoic landscape evolution in the northern Sierras Pampeanas,Argentina, Basin Res., doi:10.1046/j.1365-2117.2003.00214.x, 2003.

Tapponnier, P., Peltzer, G., and Armijo, R.: On the mechanics of the collision between India and Asia, in: Collision Tectonics, edited by: Coward, M. P. and Ries, A. C., Geol. Soc. Lond. Spec. Publ., 19, 115-157, 1986.

Thiede, R., Bookhagen, B., Ramon Arrowsmith, J., Sobel, E. R., and Strecker, M. R.: Climatic control on areas of rapid exhumation along the Southern Himalayan Front. Earth Planet. Sci. Lett., 222, 791-806, 2004.

Vassallo, R., Ritz, J.-F., Braucher, R., Jolivet, M., Carretier, S., Larroque, C., Chauvet, A., Sue, C., Todbileg, M., Bourlès, D., Arzhannikova, A., and Arzhannikov, S.: Transpressional tectonics and stream terraces of the Gobi-Altay, Mongolia. Tectonics, doi:10.1029/2006TC002081, 2007a.

Vassallo, R., Jolivet, M., Ritz, J.-F., Braucher, R., Larroque, C. H., Sue, C., Todbileg, M., and Javkhlanbold, D.: Uplift age and rates of the Gurvan Bogd system (Gobi-Altay) by apatite fission track analysis, Earth Planet. Sci. Lett., 259, 333-346, 2007 b.

Vincent, S. J. and Allen, M. B.: Evolution of the Minle and Chaoshui Basins, China : Implications for Mesozoic strike-slip basin formation in Central Asia, Geol. Soc. Am. Bull., 111, 725742, 1999.

Wang, B., Faure, M., Cluzel, D., Shu, L. S., Charvet, J., and Meffre, S.: Late Paleozoic tectonic evolution of the northern West Tian Shan, NW China, Geodynam. Ac., 19, 237-247, 2006.

Wang, B., Shu, L. S., Cluzel, D., Faure, M., and Charvet, J.: Geochemical constraints on Carboniferous volcanic rocks of Yili Block (Xinjiang, NW China); implication on tectonic evolution of Western Tianshan, J. Asian Earth Sci., 29, 148-159, 2007a.

Wang, B., Chen, Y., Zhan, S., Shu, L.S., Faure, M., Cluzel, D., Charvet, J., and Laurent-Charvet, S.: Primary Carboniferous and Permian paleomagnetic results from the Yili Block (NW China) and their geodynamic implications on the evolution of Chinese Tianshan Belt, Earth Planet. Sci. Lett., 263, 288-308, 2007b.

Wang, B., Cluzel, D., Shu, L. S., Faure, M., Charvet, J., Chen, Y., Meffre, S., and de Jong, K.: Evolution of calc-alkaline to alkaline magmatism through Carboniferous convergence to Permian transcurrent tectonics, western Chinese Tianshan, Int. J. Earth Sci., 98, 1275-1298, 2009.

Wang, S. E. and Gao, L. Z.: SHRIMP U-Pb dating of zircons from tuff of Jurassic Qigu Formation in Junggar Basin, Xinjiang, Geol. Bull. China, 31, 503-509, 2012.

Wang, Z. X., Li, T., Zhang, J., Liu, Y. Q., and Ma, Z. J.: The uplifting process of the Bogda Mountain during the Cenozoic and its tectonic implication, Sci. China Ser D, 51, 579-593, 2008.

Wartes, M. A., Carroll, A. R., and Greene, T. J.: Permian sedimentary record of the Turpan-Hami basin and adjacent regions, northwest China: Constraints on postamalgamation tectonic evolution, Geol. Soc. Am. Bull., 114, 131-152, 2002.

Whipple, K. X.: The influence of climate on the tectonic evolution of mountain belts, Nat. Geosci., 2, 97-104, 2009.

Whipple, K. X. and Meade, B. J.: Orogen response to changes in climatic and tectonic forcing, Earth Planet. Sci. Lett., 243, 218 228, 2006 
Willet, S. D.: Orogeny and orography: The effects of erosion on the structure of mountain belts, J. Geophys. Res., 104, 28957-28981, 1999.

Windley, B. F., Allen, M. B., Zhang, C., Zhao, Z. Y., and Wang, G. R.: Paleozoic accretion and Cenozoic redeformation of the Chinese Tien Shan range, central Asia, Geology, 10, 128-131, 1990.

Wobus, C. W., Hodges, K. V., and Whipple, K. X.: Has focused denudation sustained active thrusting at the Himalayan topographic front? Geol. Soc. Am. Bull., 31, 861-864, 2003.

Xia, L. Q., Xu, X. Y., Xia, Z. C., Li, X. M., Ma, Z. P., and Wang, L .S.: Petrogenesis of Carboniferous rift-related volcanic rocks in the Tianshan, nortwestern China, Geol. Soc. Am. Bull., 116, 419-433, 2004

Xia, L. Q., Li, X. M., Xu, X. Y., Xia, Z. C., Ma, Z. P., and Wang, L. S.: Petrogenetic evolution of the Bayan Gol ophiolite - geological record of an early Carboniferous "Red Sea type" ocean basin in the Tianshan Mountains, Northwestern China, Ac. Geol. Sin., 79, 174-192, 2005.

Xia, L. Q., Xia, Z. C., Xu, X. Y., Li, X. M., and Ma, Z. P.: Relative contributions of crust and mantle to the generaton of the Tianshan carboniferous rift-related basic lavas, northwestern China, J. Asian Earth Sci., 31, 357-378, 2008.

Xia, L. Q., Xu, X., Li, X., Ma, Zh., and Xia, Z.: Reassesment of petrogenesis of Carboniferous-Early Permian rift-related volcanic rocks in the Chinese Tianshan and its neighbouring areas, Geosci. Front., 3, 445-471, 2012.

Xiao, X. C., Tang, Y. Q., Feng, Y. M., Zhu, B. Q., Li, J. Y., AND Zhao, M.: Tectonic Evolution of Northern Xinjiang and its Adjacent Regions, Geological Publishing House, Beijing, p. 169, 1992. (in Chinese with English abstract)
Yang, W., Jolivet, M., Dupont-Nivet, G., Guo, Zh., Zhang, Zh., and Wu, Ch.: Late Paleozoic to Quaternary tectonic evolution of the southern Junggar basin (Northwest China) revealed by detrital U-Pb zircon geochronology, Basin Res., 24, 1-22, 2012.

Yin, A.: Cenozoic tectonic evolution of the Himalayan orogen as constrained by along-strike variation of structural geometry, exhumation history, and foreland sedimentation, Earth Sci. Rev., 76, 1-131, 2006.

Yin, A.: Cenozoic tectonic evolution of Asia: A preliminary synthesis. Tectonophysics, 488, 293-325, 2010.

Zhang, Zh., Zhu, W., Shu, L., Wan, J., Yang, W., Su, J., and Zheng, B.: Apatite fission track thermochronology of the Precambrian Aksu blueschists, NW China: Implications for thermo-tectonic evolution of the north Tarim basement, Gondwana Res., 16, 182$188,2009$.

Zhao, K., Li, X., Dodson, J., Zhou, X., and Atahan, P.: Climate instability during the last deglaciation in central Asia, reconstructed by pollen data from Yili Valley, NW China, Rev. Palaeobot. Palyno., 189, 8-17, 2013.

Zhao, Z. H., Xiong, X. L., Wang, Q., Wyman, D. A., Bao, Z. W., Bai, Z. H., and Qiao, Y. L.: Underplating-related adakites in Xinjiang Tianshan, China. Lithos, 102, 374-391, 2008.

Zonenshain, L. P., Kuzmin, M. I., and Natapov, L. M.: The URSS Territory Plate Tectonics, Vol. 1, Nedra, Moscow, 328 pp, 1990a.

Zonenshain, L. P., Kuzmin, M. I., and Natapov, L. M.: The URSS Territory Plate Tectonics, Vol. 2, Nedra, Moscow, 334 pp, $1990 \mathrm{~b}$.

Zorin, Y. A., Novoselova, M. R., Turutanov, E. K., and Kozhevnikov, V. M.: Structure of the lithosphere in the Mongolia-Siberian mountainous province, J. Geodyn., 11, 327$342,1990$. 